\title{
Urocortins in the mammalian endocrine system
}

\author{
Caterina Squillacioti ${ }^{1 \dagger}$, Alessandra Pelagalli ${ }^{2,3 \dagger}$, Giovanna Liguori ${ }^{1 *}$ (D) and Nicola Mirabella ${ }^{1}$
}

\begin{abstract}
Urocortins (Ucns), peptides belonging to the corticotropin-releasing hormone (CRH) family, are classified into Ucn1, Ucn2, and Ucn3. They are involved in regulating several body functions by binding to two $G$ protein-coupled receptors: receptor type 1 (CRHR1) and type 2 (CRHR2). In this review, we provide a historical overview of research on Ucns and their receptors in the mammalian endocrine system. Although the literature on the topic is limited, we focused our attention particularly on the main role of Ucns and their receptors in regulating the hypothalamic-pituitary-adrenal and thyroid axes, reproductive organs, pancreas, gastrointestinal tract, and other tissues characterized by "diffuse" endocrine cells in mammals. The prominent function of these peptides in health conditions led us to also hypothesize an action of Ucn agonists/antagonists in stress and in various diseases with its critical consequences on behavior and physiology. The potential role of the urocortinergic system is an intriguing topic that deserves further in-depth investigations to develop novel strategies for preventing stress-related conditions and treating endocrine diseases.
\end{abstract}

Keywords: Corticotropin-releasing hormone receptors, Endocrine system, Mammals, Urocortin

\section{Background}

Urocortins (Ucns) belong to the corticotropin-releasing hormone $(\mathrm{CRH})$ family, which includes $\mathrm{CRH}$, fish urotensin I, frog sauvagine, Ucn1, Ucn2 (or stresscopinrelated peptide), and Ucn3 (or stresscopin) [1-4]. This family is a critical regulator of the hypothalamic-pituitary-adrenal (HPA) axis, leading to subsequent release of adrenocorticotropic hormone and corticosteroids $[5,6]$. These 38-41-amino acid peptides are structurally related and are highly conserved among different animal species [7, 8] (Fig. 1a). All peptides are encoded by separate genes. These peptides are found in the central nervous system (CNS) as well as in peripheral tissues including the digestive, cardiovascular, immune, reproductive, and endocrine systems [9-15]. The physiological effects of these peptides are mediated through seven transmembrane domain G-protein-coupled receptors (GPCRs): CRH receptor type 1 (CRHR1) and CRH receptor type 2

\footnotetext{
*Correspondence: giovanna.liguori@unina.it

†'Squillacioti Caterina and Pelagalli Alessandra contributed equally to this work

${ }^{1}$ Department of Veterinary Medicine and Animal Productions, University of Naples Federico II, Via Veterinaria 1, 80137 Naples, Italy Full list of author information is available at the end of the article
}

(CRHR2). CRHR1 and CRHR2 have differential binding affinities to each of the CRH family members. CRHR1 shows high affinity to $\mathrm{CRH}$ and Ucn1, but no appreciable binding affinity to Ucn 2 and Ucn3. CRHR2 primarily binds to Ucn1, Ucn2, and Ucn3 with greater affinity than to CRH [3, 8, 16] (Fig. 1c). These receptors also have different expression patterns in the central and peripheral tissues [17]. CRHR1 is primarily expressed in the CNS and the anterior pituitary. The CRHR2 receptor is expressed primarily in extra-CNS sites. Two separate genes encode the CRH receptors [18]. In addition to binding to two receptors, $\mathrm{CRH}$-related peptides also bind to $\mathrm{CRH}$-binding protein (CRHBP) [19]. CRHBP, a $37-\mathrm{kDa}$ glycoprotein, limits ligand availability [20].

Ucns have been shown to be associated with a variety of physiological functions in different animal species, including domestic animals. These functions include stress [21-24], feeding behaviors and energy homeostasis [25-31], immune responses [32], cardiovascular regulation [33-35], inflammation regulation [36], reproduction [37], and hormone release from the pituitary [38, 39].

Moreover, the presence of Ucns and their receptors was reported in several mammalian endocrine glands, thus suggesting a role for this peptide in regulating endocrine 


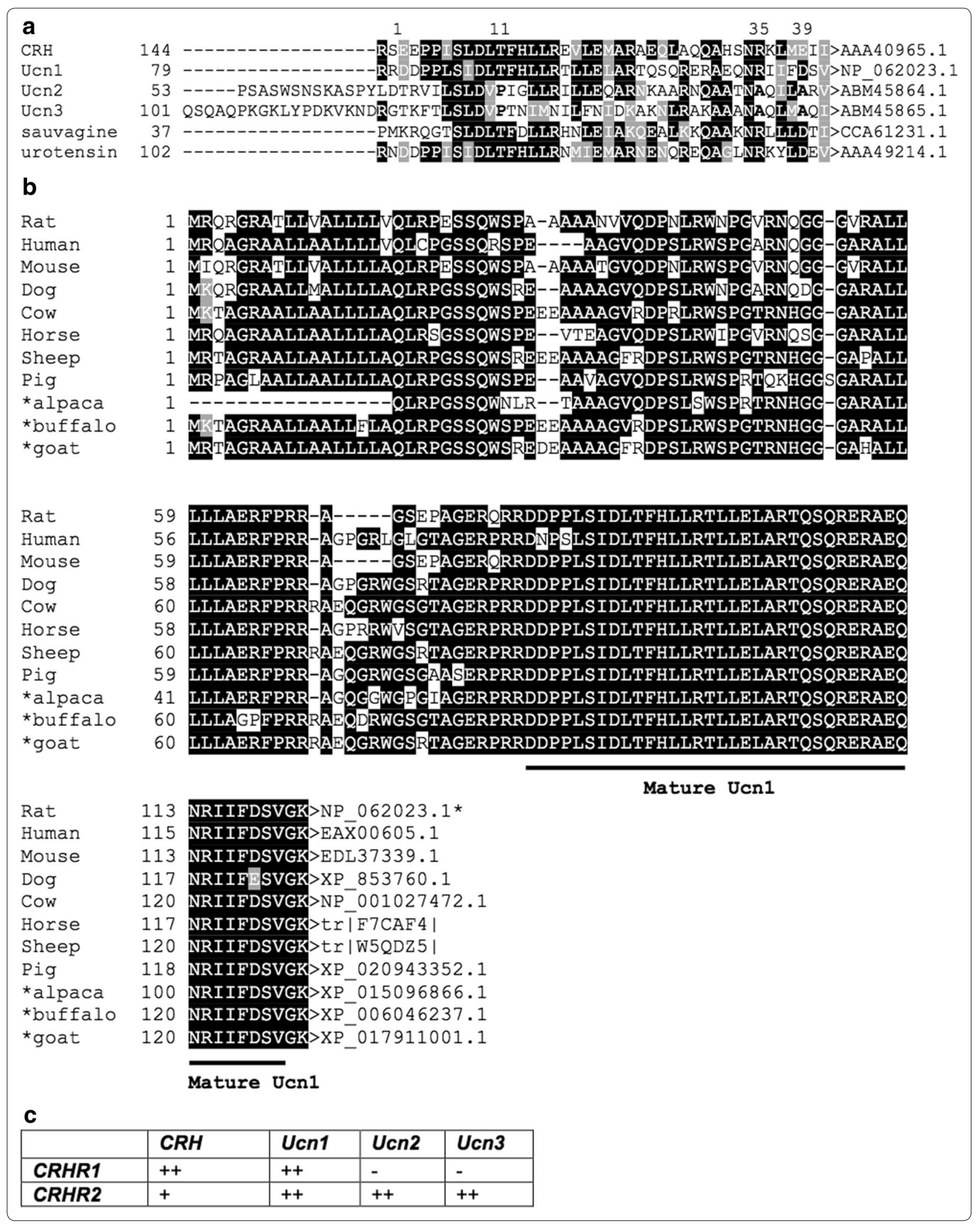


(See figure on previous page.)

Fig. 1 a Multiple alignment of the amino acid sequence of corticotropin-releasing hormone (CRH) and CRH-related peptides. The rat Ucn1 has $45 \%$ similarity to $\mathrm{rCRH}, \mathrm{Ucn} 2$ has $34 \%$ similarity to $\mathrm{CRH}$, Ucn3 has $26 \%$ similarity to $\mathrm{CRH}$, frog Sauvagine has $50 \%$ similarity to $\mathrm{CRH}$, fish Urotensin has $50 \%$ similarity to $\mathrm{CRH}$. $\mathbf{b}$ Multiple alignment of the amino acid sequence of urocortin precursors from different species including some domestic animals. Rat mature Ucn 1 has $99-100 \%$ similarity to dog, cow, horse, sheep, pig, alpaca, buffalo, and goat Ucn1. Ucn1 sequences have 99-100\% similarity among different domestic animal species. Sequences were aligned using Clustal W then highlighted using BoxShade 3.21, which shades conserved residues according to whether they are completely conserved (black) or similar (gray). Hyphens indicate gaps in the sequence among the species. Asterisk indicates "predicted sequences". c Binding affinity of CRHR-ligands. CRHR1 binds CRH as well as Ucn1, but not Ucn2 and Ucn3, whereas CRHR2 binds Ucns with a higher binding affinity than CRH. A proline residue at position 11 (bold letter) is found only in CRHR2-selective ligands, Ucn2 and Ucn3. These peptides also contain alanine residues at positions 35 and 39 (bold letters)

functions [13-15, 40, 41]. This review outlines existing knowledge on the expression and function of Ucns and their receptors in the mammalian endocrine system.

\section{Search strategy}

This review is based on a search in PubMed (http://www. ncbi.nlm.nih.gov/pubmed) using the terms "urocortin, corticotropin-releasing hormone receptors, mammals, endocrine system". The title and abstract of the obtained hits were evaluated and articles referring to urocortins in the endocrine system were obtained and assessed in detail. In addition, our own archives were used as a source of additional information. Our extensive experience with the expression of the urocortinergic system in the thyroid gland and testis of mammals was used to critically evaluate the literature.

\section{Review}

\section{Urocortins and CRH-receptors: general structure and biochemistry}

Ucn1 is a 40-amino acid neuropeptide cloned from rat brain tissue that has a $45 \%$ similarity with CRH and a $60 \%$ identity with urotensin I [8] (Fig. 1a). Ucn1 is composed of a single alpha helix structure [42]. Human Ucn consists of 124 amino acids, 80 of which form the "precursor peptide". The amino acids Arg-Arg in position 81-82 and Lys-Gly in position 123-124 undergo proteolysis, constituting the site of detachment from the precursor and the C-terminal sequence, respectively. The mature Ucn1 peptide is generated by cleavage of 42 amino acids from the $\mathrm{C}$-terminus followed by amidation to eliminate the C-terminal dipeptide Gly-Lys [43]. Since all the mammalian forms of Ucn1 discovered to date exhibit a high degree of sequence conservation, the functions of this peptide may be similar or identical across mammalian species. Ucn1 has been identified in humans, rats, mice, hamsters, and sheep $[8,43,44]$ with high sequence homology [44]. In addition, the mature Ucn 1 sequence is highly conserved in different domestic animal species (99-100\% identity to rat, mouse or human, and among them) (Fig. 1b). The gene encoding Ucn1 is located on the short arm of chromosome $2(2 \mathrm{p} 23-\mathrm{p} 21)$. The genomic structure of the Ucn1 gene is similar to that of the CRH gene, with two exons and one intron. The entire precursor protein is located entirely on the second exon $[8,43]$. Ucn 1 binds both CRH receptors with high affinity [42].

Ucn2 is a 38 -amino acid peptide related to CRH that shows homology with rat and human CRH (has about $34 \%$ similarity to $\mathrm{rCRH}$ and hCRH), hUcn1 (43\%) and hUcn3 (37-40\%) [3, 45]. Ucn2 and Ucn3, which were discovered during human genome mapping, are selective agonists of CRHR2 [45]. Human Ucn2 consists of two alpha helices, a short $\mathrm{N}$-terminus and a long $\mathrm{C}$-terminus, thus resulting in a helix-loop-helix structure. This structure is important for interaction with specific receptors [42]. The human gene encoding Ucn2 is located on chromosome 3 and the transcription of this gene is upregulated by glucocorticoids, suggesting that Ucn 2 is involved in the stress response pathway $[3,46]$.

Ucn3 (also known as stresscopin) is composed of 38 amino acids and has about $20-40 \%$ similarity to $\mathrm{h} / \mathrm{rCRH}$ and Ucn1. Both Ucn2 and Ucn 3 share a sequence similarity of up to $40 \%$ [45]. The proline residue at position 11 and alanine residues at positions 35 and 39 are characteristic of CRHR2-selective ligands Ucn2 and Ucn3 [47] (Fig. 1a, c). Human Ucn3 consists of a small $\mathrm{N}$-terminal helix and a long C-terminal alpha helix containing 20 residues. This type of helix-loop-helix is critical for interactions with specific receptors [42]. The links between the $\mathrm{N}$ - and $\mathrm{C}$ - terminal helices are thought to be crucial to ligand-receptor interactions [42]. The human gene encoding Ucn3 is located on chromosome 10 [48].

CRHR1 and CRHR2 are class B1 GPCRs consisting of seven transmembrane helices with an $\mathrm{N}$-terminal extracellular ligand-binding domain (ECD). CRHR1, a 415amino acid protein, shares $70 \%$ amino acidic sequence identity with CRHR2, but there is divergence at the $\mathrm{N}$-terminal ECD. This is consistent with distinct pharmacological properties and agonist selectivity of both receptors. CRHR1 binds CRH and Ucn1, but not Ucn2 or Ucn3, with similar high affinity (Fig. 1c). On the contrary, CRHR2 binds all Ucns with higher binding affinity than 
for $\mathrm{CRH}$, suggesting that these peptides may be its natural ligands $[3,8,17,18,45,48]$. CRHR1 and CRHR2 are coded by two different genes. CRHR1 has been cloned in different mammalian species: humans, rats, mice, and sheep [18, 49-52]. The genes for human and rat CRHR1 contain 14 and 13 exons, respectively [53, 54], and produce several alternatively spliced isoforms. In humans, eight CRHR1 isoforms have been described [18, 47, 55, 56]. In rats, there are three CRHR1 isoforms [53]. In mice, there are four isoforms, equivalent to some human isoforms CRHR1alpha [50, 56]. The human CRHR2 gene contains 12 exons. Three major functional isoforms, alpha (411 amino acids), beta (438 amino acids), and gamma (397 amino acids), encoded by transcripts with alternative first exons [57] differ only in the N-terminal sequence comprising the signal peptide and part of the ECD (amino acids 18-108 of CRHR2 alpha). In mice, an mRNA splice variant of CRH-R2 $\alpha$ (sCRH-R $2 \alpha$ ) was identified that encodes the receptor's ligand-binding extracellular domain but terminates before the transmembrane domains. This variant was therefore predicted to serve as a secreted decoy receptor, mimicking the ability of $\mathrm{CRH}$-binding protein to sequester free $\mathrm{CRH}$ [58]. This soluble variant is efficiently translated but not necessarily secreted [59].

CRHBP is a $37-\mathrm{kDa}$ glycoprotein and the bound form of $\mathrm{CRH}$ and its related peptides is biologically inactive [60]. CRHBP, in this manner, may have a role in modulating the effects of CRHR-ligand binding [20,61]. Similar to CRH and CRHRs, CRHBP is widely distributed throughout the brain [19]. In humans, but not known in rodents, CRHBP is also synthesized in the liver and placenta, and secreted into the general circulation. The presence of CRHBP in the CNS suggests that CRHBP may have additional roles. CRHBP also seems to facilitate some of the actions of CRH/Ucn1 in a CRHR2-dependent manner. In particular, $\mathrm{CRH}$ requires $\mathrm{CRH}-\mathrm{BP}$ to potentiate NMDA receptors via CRHR2 in dopamine neurons [62]. Recently, Slater and colleagues demonstrated that CRF-BP acts as an escort protein for CRF2 $\alpha$ R, facilitating its presence in the plasma membrane. These authors showed that CRF-BP physically interacts with CRF $2 \alpha R$ in an isoform-specific manner, because no interaction was detected between CRF-BP and CRF2 $\beta R$ [63].

Activated CRHR1 and CRHR2 primarily signal by stimulating $G$ protein (Gs) coupling, resulting in the induction of the cyclic adenosine monophosphate (cAMP)-protein kinase A (PKA) and the extracellular signal-regulated kinase-mitogen-activated protein kinase (ERK-MAPK) pathways. Activation of PKA leads to the phosphorylation of transcription factors like cAMP response element binding protein (CREB), which in turn increases the expression of downstream target genes [64].
CRHRs also interact with other $\mathrm{G}$ proteins, including $\mathrm{Gq}$, $\mathrm{Gi}$, and $\mathrm{Gi} 1 / 2$, thus activating phospholipase $\mathrm{C}$ variants (PLCs) and resulting in the activation of ERK1 and ERK2 and an increase in intracellular $\mathrm{Ca}^{2+}$ concentration [47, 65]. Many other regulatory systems seem to modulate CRHR activity but are not well understood and warrant further study.

\section{Hypothalamic-pituitary-adrenal and thyroid axis}

Recent research has focused on possible roles played by Ucns and their cognate receptors CRHR1 and CRHR2, respectively on the HPA and thyroid axes. In particular, these studies demonstrated a relationship between their possible tissue distribution in these regions and their specific regulation in mammals.

Based on previous data reporting the role of CRH in multiple regulation mechanisms at the level of these regions and in consideration of the high correlation between Ucns and CRH, different studies have aimed to analyze the possible differences in the role of these peptides with respect to $\mathrm{CRH}$. Since the HPA axis plays a pivotal role in regulating fundamental processes of all living organisms [66], the participation of these peptides in different activities of this system may be significant. It is well known that the HPA axis not only involves the functions of three endocrine glands (hypothalamus, pituitary, and adrenal glands), but also is widely involved in different physiological processes such as regulation of the stress response [67], digestion, immune function, behavior, sexuality, and energy storage and expenditure.

Similarly, the HPT axis plays a pivotal role in stimulating the normal secretion of thyroid hormone and thus contributes to maintain cardiovascular, bone, and liver function, and energy homeostasis [68]. Such complex activities of both the HPA and HPT axis are deeply controlled by complex regulatory circuits that permit communication between different regions, either through cell-to-cell communication (paracrine signaling) and within the same cell communication (autocrine signaling). In this context, studies concerning Ucn distribution at the level of these endocrine axes in domestic animals (Table 1) indicate their possible involvement in regulating numerous biological functions. These findings could clarify previous data reports often overshadowed by studies on CRH and its analogues, thus leaving aside many other angles of specific research.

Ucn1, the most-studied Ucn, has been characterized in terms of its localization in different domestic animal species, also focusing on its possible role in the CNS. In particular, Ucn 1 identification in cats, particularly within the Edinger-Westphal (EW) nucleus [69], which differs from that observed in ovine species, where the peptide was observed in the hypothalamic region, could suggest 
Table 1 Expression of urocortins (Ucns) and their relative receptors, CRHRs, in endocrine system tissues of domestic animals

\begin{tabular}{|c|c|c|c|c|c|c|c|}
\hline Endocrine system & Animal species & Ucn 1 & Ucn2 & Ucn3 & CRHR1 & CRHR2 & References \\
\hline \multirow[t]{4}{*}{ HPA } & Cat & + & n.d. & n.d. & n.d. & n.d. & [67] \\
\hline & Bird & n.d. & n.d. & + & n.d. & n.d. & [153] \\
\hline & Cow & + & n.d. & n.d. & + & + & [13] \\
\hline & Sheep & + & n.d. & n.d. & n.d. & n.d. & {$[39,68]$} \\
\hline \multirow[t]{2}{*}{ HPT } & Cow & + & n.d. & n.d. & + & + & {$[15]$} \\
\hline & Horse & + & n.d. & n.d. & + & + & {$[14]$} \\
\hline \multirow[t]{3}{*}{ Female gonads } & Pig (ovary-CL) & + & n.d. & n.d. & + & + & {$[117]$} \\
\hline & Pig (ovary) & + & n.d. & n.d. & + & - & [117] \\
\hline & Sheep (placentome) & + & n.d. & n.d. & + & n.d. & [126] \\
\hline \multirow[t]{2}{*}{ Male gonads } & Dog (testis) & + & n.d. & n.d. & + & + & [104] \\
\hline & Alpaca (epididymis) & + & n.d. & n.d. & + & + & [111] \\
\hline
\end{tabular}

HPA hypothalamic-pituitary-adrenal axis, HPT hypothalamic-pituitary-thyroid axis, CL corpus luteum, n.d. not determined

a particular role in this area as well as a specific binding activity towards $\mathrm{CRH}$ receptors, if compared with its homolog human Ucn1 [70].

Considering that in rats, Ucn1 localizes not only to the EW [71, 72] but also to lateral superior olivary (LSO) and supraoptic nuclei [73], the idea of a different modulation in Ucn 1 activity in domestic animal species should potentially be considered. The presence of Ucn 1 in cats at the EW nucleus suggests a specific and confined role of this peptide, although the functional studies on this topic are limited. Moreover, it should be considered that the EW nucleus and the location of Ucn cell population differ among animal species (particularly between cats and macaque monkeys), although, as described for monkeys, in some cases, the distribution of the perioculomotor (pIIIU) cell population is likely to overlap with that of $\mathrm{C}$ - and S-group motorneurons that supply non-twitch muscle fibers in the extraocular muscles [69]. This organization of Ucn cell populations and their projections suggest possible functional implications of Ucn1 and of the use of specialized neurotransmitters, that currently remain an open and testable hypothesis.

The direct activity of Ucn1 on ACTH release from the pituitary has been assessed in a complex research project in sheep focused on evaluating the endocrine effects of Ucn1 in experimental heart failure [67].

In contrast, in several studies conducted on rat species, the presence of Ucn $1 \mathrm{mRNA}$ in the brain and pituitary and the biological effects of Ucn1 after its intracerebroventricular (ICV) or intravenous (IV) administration suggest its complex role in regulating the HPA axis [38, 73].

In 2011, Ucn1 as well as its relative receptors CRHR1 and CRHR2 were isolated and characterized in the bovine adrenal gland, showing their particular distribution in both adrenal cortex and medulla [13]. Such results, confirmed by the use of histological and biochemical techniques, permit us to speculate about the role of Ucn 1 in the intra-adrenal CRH-based regulatory system to be achieved by an autocrine mechanism [13]. Moreover, other data demonstrating the role of Ucn1 in adequate control of steroid secretion come from studies in lactating dairy cows with or without ovarian follicular cysts [74]. Together, these data confirm previous findings obtained from studies using knockout (KO) mouse models lacking Ucn1, indicating cellular hypotrophy of the outer adrenal cortex and lower expression levels of Cyp11b2 [75]. However, Ucn1 knockout mice show no alterations in HPA axis activity [76, 77]. In addition, in mice deficient in Ucn2 or Ucn3, as single, double, or triple knockout in combination with Ucn1, alterations of HPA axis functions have not been observed [78-80]. The use of these models is undoubtedly important to clarify some metabolic functions of Ucns.

Studies conducted by directly administering Ucn 1 have contributed to a better knowledge of the mechanisms exerted by Ucn 1 and, in some cases, on its receptors CRHR1 and CRHR2 on the HPA axis of domestic animals (Table 2). In particular, Parrott et al. [81] demonstrated that Ucn1, when administered by intracerebroventricular injection (ICV), induced an increase in cortisol secretion similar to that induced by $\mathrm{CRH}$, albeit the latter showed a higher stimulatory activity. Similar results were observed considering behavioral activation parameters (such as changes in posture and orientation, and engagement in vigorous oro-nasal activity). The interpretation of these results should take into account that, in contrast to humans and rats, for which the CRHR distribution in the CNS has been identified [82], pig Ucn1 CRHR2 has not yet been discovered. Therefore, considering that 
Table 2 Effects of administering urocortins (Ucns) and their relative receptors, CRHRs, on the hypothalamic-pituitaryadrenal axis of domestic animals

\begin{tabular}{|c|c|c|c|c|c|c|c|c|}
\hline Animal species & Treatment & Uen 1 & Uen2 & Ucn3 & CRHR1 & CRHR2 & Effects & References \\
\hline Bird & ICV & n.d. & n.d. & + & n.d. & n.d. & $\uparrow$ Ghrelin & [154] \\
\hline Ewe & ICV & + & n.d. & n.d. & n.d. & n.d. & $\begin{array}{l}\downarrow \text { Food intake } \\
\uparrow \mathrm{GH}, \mathrm{LH} \text {, cortisol, leptin }\end{array}$ & [84] \\
\hline Gilt & ICV & + & n.d. & n.d. & n.d. & n.d. & $\begin{array}{l}\downarrow \text { LH and food intake } \\
\uparrow \text { Cortisol and ACTH }\end{array}$ & [85] \\
\hline Horse (pony) & ICV & + & n.d. & n.d. & n.d. & n.d. & $\begin{array}{l}\uparrow \text { Cortisol } \\
\downarrow \text { Food intake }\end{array}$ & [155] \\
\hline Pig & Central injection & + & n.d. & n.d. & + & n.d. & $\uparrow$ Cortisol & {$[81,156]$} \\
\hline Sheep & ICV & + & n.d. & n.d. & n.d. & n.d. & $\begin{array}{l}\uparrow \text { Urine excretion } \\
\downarrow \text { Food intake }\end{array}$ & [157] \\
\hline
\end{tabular}

ICV intracerebroventricular, n.d. not determined, GH growth hormone, $L H$ luteinizing hormone, $A C T H$ adrenocorticotropic hormone

Ucn1 activity mostly occurs through CRHR2, the different selectivity of CRHRs varies with animal species [83]. This last consideration could be important to evaluate the effect of Ucn1 in sheep, even if the recorded effects were similar between Ucn1 and CRF in this species [84].

The possibility of Ucn 1 to exert its activities by binding to its specific CRHR2, which has not yet been identified in all tissues in different animal species, permits speculation that Ucn 1 exerts its activity in a broad range of areas. In particular, the integrative role of Ucn 1 as a mediator in the interrelations between systems of appetite regulation, reproduction, growth, and metabolic balance has been evidenced in a study in gilts [85].

More recently, expression of Ucn1, CRHR1, and CRHR2 has been investigated in both equine and bovine thyroid glands $[14,15]$. Such studies, supported by the use of multiple techniques (immunohistochemistry, western blotting, and RT-PCR), have greatly contributed to knowledge on the potential role of Ucn1 in this gland in domestic animals. In particular, in horses, immunohistochemical results revealed for the first time that Ucn1 expression specifically localizes in thyroid follicular cells, although CRHR2 was detected in both parafollicular and C-cells [14]. Results from bovine species [15] revealed a different distribution of Ucn1 and CRHR2 at the cellular level, confirmed by immunoreactivity in both follicular and parafollicular cells. Conversely, CRHR1 immunoreactivity was concentrated in the smooth musculature of blood vessels in both animal species, thus suggesting a potential role in modulating the thyroid gland blood flow, as previously reported in rats and mice [86-88].

In particular, western blotting showed that Ucn1 presents as a band corresponding to a molecular weight approximately of $16 \mathrm{kDa}$, comparable with the mammalian Ucn precursor (122-amino acid protein) [8, 13, 43]. Its characterization suggests a role in calcitonin secretion via CRHR2 in an autocrine/paracrine manner, probably adjuvated by other CRHR2 ligands, such as Ucn2 and Ucn3. All these findings suggest a possible role of follicular cells in regulating iodine uptake, supported by specific local blood flow. Such data confirm previous results by studies on pathological conditions in humans [89]. In particular, results from a case of multiple endocrine neoplasia type II showed the presence of cells highly expressing $\mathrm{CRH}, \mathrm{Ucn} 1$, and Ucn3.

Together, these data indicate that $\mathrm{CRH}$ and Ucns play a role in secreting ACTH and glucocorticoid hormones. However, further studies are needed to investigate the possible involvement of Ucns in thyroid hormone synthesis. Regarding the parathyroid, only a functional study by Asakawa et al. [90] demonstrated that the influence of parathyroid hormone-related protein on food intake by gastric emptying is related to Ucn2 and Ucn3 expression.

More recently, new promising perspectives regarding the involvement of Ucns (particularly Ucn2 and Ucn3) in the field of stress pathophysiology have been shown. This area of research is attractive considering that different forms of stress (physical and psychological) interfere by multiple mechanisms (central and peripheral) on several body activities (metabolism, reproduction, behavior, host defense, etc.). In this regard, although several studies on Ucn involvement in stress have been conducted in laboratory animals $[78,91-94]$, more research has been focused on domestic animals. Moreover, it should be taken into account that Ucns and CRH have been found in brain areas known to be important not only for body fluid and electrolyte homeostasis but also for behavior. In addition, Ucns (Ucn2 and Ucn3) seem to be particularly involved in regulating mammalian social behavior via activation of CRFR2 [95].

Some reports, based on results showing that stress can cause an increase in $\mathrm{Na}$ intake similar to the effect obtained by peripheral Ucn administration in several different species, including sheep [96], rabbits [97], rats 
[98], and mice [99, 100], have stimulated interest on this research area. In sheep and rats, the appetite-related effects appear to occur via ACTH on adrenal gland hormones, because it can be prevented by adrenalectomy $[96,98]$. On the other hand, ACTH can cause an increase in $\mathrm{Na}$ intake in adrenalectomized wild rabbits [97]. Weisinger et al. [101] demonstrated that Ucn, administered by ICV infusion, inhibited $\mathrm{Na}$ intake in sheep. In particular, Ucn inhibited not only need-free $\mathrm{Na}$ intake but also the high $\mathrm{Na}$ intake induced by peripheral ACTH, further indicating a definite inhibitory action. Taken together, these data suggest that Ucn and CRH can influence some, but not all, activities involved in $\mathrm{Na}$ appetite-possibly only those initiated by corticosteroids. The mechanism remains to be clarified completely, because the brain nuclei that mediate $\mathrm{Na}$ appetite in sheep are not fully known. Presumably, other physiological processes entrained by stress that are important in determining the outcome on $\mathrm{Na}$ appetite need further investigation. In the meantime, studies in rats indicate that steroid-induced, but not $\mathrm{Na}$ depletion-induced, $\mathrm{Na}$ appetite is mediated in the medial amygdala [102], a brain area beyond the blood-brain barrier. Moreover, experiments analyzing the specific activity of urocortin with respect to the wellknown CRH, demonstrated that the two peptides could have both central and peripheral actions.

More recently, in a study regarding chronic social stress (CSS) in pigs that analyzed major factors driving gastrointestinal (GI) pathophysiology, Ucn2 mRNA was found to be up-regulated in the colon of pigs under CSS. These data have further confirmed the peripheral action of Ucn [103].

The data observed in domestic animal species could represent useful supporting evidence to that obtained in other species such as mice and rats, thus opening a new door to analyze the key role of Ucns related to biochemical, hormonal, and behavioral alterations in response to stress. The possible involvement of Ucns in the effects of stress should be of particular interest in farming animal species where specific conditions (food and/or water restriction or deprivation, social interaction, environmental conditions, animal handling, etc.) can alter the normal body homeostasis, which affects various physiological aspects and thus their performance. This concept also deserves further study, since Ucns may be involved in stress-related psycho-pathologies (depression and anxiety) [60], and discriminating between the specific action of Ucns might help determine their differential roles in regulating the stress response.

\section{Gonads and reproductive system}

Studies of the Ucns within the endocrine organs helped define the localization and physiological roles of these peptides and their receptors in the gonads and in diffuse cells of the reproductive system. The gonads play a pivotal role in regulating gametogenesis and steroidogenesis, thereby influencing reproductive performance. In this context, investigating Ucns in domestic and livestockin both healthy and pathological conditions might be relevant for improving knowledge regarding reproduction, particularly in clinical practices. Few studies regarding the presence of Ucns and CRHRs in the male gonads of domestic animals have been performed, and one of these studies was conducted by our research group [104] (Table 1). We described Ucn1 and CRHRs in the testes of normal and cryptorchid dogs by means of immunohistochemistry, western blot, and real-time RT-PCR. Particularly, Ucn1 and CRHR2 were observed in the tubular and interstitial compartments of normal and cryptic gonads, leading us to hypothesize that these substances may play a role in regulating mitotic and apoptotic events occurring during spermatogenesis and in regulating steroidogenesis by an autocrine/paracrine mechanism. On the other hand, the distribution of CRHR1 in the muscular cells of blood vessels within the normal and cryptic gonads suggests a role of Ucn1, via CRHR1, in regulating canine testicular blood flow. The most interesting finding of this research was a decrease in Ucn1 and CRHR2 mRNA levels in cryptic canine testis, suggesting that these peptides play a role in preventing neoplasia. This last aspect deserves particular attention, as the Ucns could represent targets for possible pharmacological or therapeutic approaches for cryptorchidism, suggesting modulation of the main testicular functions, and consequently, reproductive performance.

These hypotheses are based on published data in humans and rodents. The only evidence of Ucn 1 and CRHRs in the human testis was demonstrated by Tezval et al. [105] who detected a possible role of these peptides in the pathophysiology of germ cell differentiation and division in normal adult and fetal testicular germ cell distribution. Most studies regarding Ucns and their receptors in the male gonads were performed in rodents, with controversial results. Particularly, Ucn1 located in mouse spermatozoa had inhibitory effects on T-type calcium channels in mouse spermatogenic cells, sperm motility, and progesterone-evoked sperm acrosome reaction, indicating that inhibition of $\mathrm{Ca}^{2+}$ channels might induce inhibitory effects of Ucn1 on male reproductive functions [106]. In rat testis, intragastric alcohol injection significantly increased mRNA levels of testicular Ucn1, but not Ucn2, Ucn3, CRHR1, or CRHR2 [12]. Although McDowel et al. [107] demonstrated the ability of Ucn1, by binding CRHR1, to elevate steroidogenic gene expression in rat and mouse fetal Leydig cells, in the rat testes, this substance seemed to interfere with Leydig cell activity 
by inhibiting human chorionic gonadotropin-stimulated steroidogenesis in primary adult rat Leydig cells [108]. However, Ucn1 may play a cytoprotective role in the germ cells from rat testis in response to ischemia-reperfusion injury through activating major anti-apoptotic proteins, as well as by activating the MAPK signaling pathway [109]. Ucn-mediated steroidogenic/steroidolytic mechanisms could represent a starting point for studying these substances in the reproductive sphere, regarding the health and disease of domestic animals. It would be interesting to deepen our understanding about the implication of these peptides in stimulating or inhibiting steroidogenic enzymes and subsequent repercussions on male fertility of domestic and farming animals, which would have great relevance for clinical practices, and eventually for therapeutic approaches. Currently, these remain only hypotheses.

Not only the male gonads, but also the diffuse "endocrine" cells, localized in the male genital tract participate in regulating reproductive functions. Particularly, Ucn1 and CRHRs were also detected in some "endocrine" cells of male reproductive organs, such as the epididymis of rats [110] and alpacas (Vicugna pacos) (Table 1) [111], as well as normal, hyperplastic, and neoplastic prostates in humans [112-114]. In the alpaca epididymis, Ucn1 and CRHR2 were found in the luminal portion of the epididymal principal cells, while CRHR1 was found in the fibromuscular cells encircling the epididymal tubules. Specifically, it has been hypothesized that Ucn1, via CRHR2, may be involved in absorptive and secretory activities of the luminal compartment of the epididymis. Moreover, via CRHR1, Ucn1 can modulate the contractility of this organ. On this basis, it might be hypothesized that Ucns in the epididymis could be involved in regulating male fertility, acting on the maturation and storage of spermatozoa and their transition throughout this organ. As in the human prostate, Ucns and their receptors might play multiple roles in regulation of prostate pathophysiology in domestic and farming animals [112-115]; therefore, future studies should investigate these peptides in other animals.

The presence of Ucns in the female gonads of domestic animals is unknown, while several studies were performed on primates, humans, and rodents. To our knowledge, the only evidence of Ucns in the female reproductive system of domestic animals involves the porcine ovary, in which these peptides seemed to be mainly implicated in regulating steroidogenesis [116, 117] (Table 1). Sakumoto et al. [116] provided evidence for the existence of mRNAs encoding CRHR1 in the porcine corpus luteum $(\mathrm{CL})$ throughout the estrous cycle. mRNA coding for CRHR1 was expressed at the highest levels in the CL of the regressed stage. CRH, via CRHR1, inhibited progesterone production by luteal cells while it did not affect estradiol- $17 \beta$ and prostaglandin F2 $\alpha$ in this species. This research group suggested that $\mathrm{CRH}$ plays one or more roles in regulating porcine CL function during the estrous cycle, especially at luteolysis (Table 1 ). Another important factor involved in ovarian function is microRNA-375 (miR-375). For this purpose, Yu et al. [117] investigated the relationship between miR-375 and $\mathrm{CRH}$ signaling molecules in the porcine ovary. PCR results showed that miR-375 and CRHR1 are expressed in the porcine ovary, whereas CRHR2 was not observed. These two factors seemed to be co-localized in ovarian granulosa cells, whereas CRHR1 was detected also in oocytes. The overexpression of miR-375 in cultured granulosa cells inhibits estrogen production. Thus, miR-375 is a key factor in regulating estrogen synthesis by mediating the CRH signaling pathway. The findings related to these substances in the female gonad of domestic animals are limited to $\mathrm{CRH}$ and its binding to cognate receptors.

In the ovarian CL of primates, Ucn1, Ucn2, CRHRs, and CRHBP were described $[118,119]$. In primate species, CRH/Ucns promoted luteal development and function but not the ovulatory process. In the human ovary, immunoreactive Ucn1 expression was found in luteinized granulosa and in theca cells of the functioning and the regressing CL, and CRHRs were higher expressed in luteinized thecal cells of regressing CL. These findings suggested that Ucns and CRH were involved in suppressing steroidogenesis [120]. mRNAs encoding both CRHRs have been found during the late follicular phase in granulosa cells, interstitial cells in the ovarian stroma, and to a greater extent in theca cells of dominant follicles [120, 121]. The increased expression of CRHR1 observed in mature human follicles implied a role of CRH-related peptides in follicular maturation [122]. Although initial studies failed to detect Ucn3 in the human ovary, it was later found in human granulosa-lutein cells of infertile women undergoing in vitro fertilization [119] and it was hypothesized to have an inhibitory effect on progesterone production [123]. Mouse models of both sexes overexpressing Ucn2 exhibited significantly higher plasma Ucn2 levels and Ucn2 expression levels in the adrenals and ovaries [124]. Ucn2 overexpression in the ovaries decreased steroidogenesis and reduced the number of follicles that had undergone ovulation, which was not associated with reduced fertility. Ucn2, Ucn3, and CRHR1 expression was also identified in rat ovaries $[45,125]$. The selectivity of the ovarian CRHR1 gene expression may suggest a biological action of CRH during the ovulatory event within the rat gonadal life cycle, in both control and stressful conditions. In line with what is described in primates and rodents, it might be 
hypothesized that even in domestic animals, CRH family proteins could modulate ovarian steroidogenesis and ovulatory events, consequently affecting reproductive function. Currently, these are only hypotheses that would require investigation.

Ucns and CRHRs were also described in the placenta and uterus, where they are involved in several endocrine processes. There is only one published description of Ucns in the placenta of domestic animals. Particularly, $\mathrm{CRH}$ and Ucn1 have been identified in the ovine placentome by immunohistochemistry [126] (Table 1). Most of the information related to this topic is limited to humans and rodents. Specifically, Ucn1, Ucn2, and Ucn3 were described in the human placenta and fetal membranes [127]. Ucn2 and Ucn3, found throughout human gestation in both the maternal and fetal membranes and decidua, have been described as regulators of placental vascular endothelial behavior and tone [128]. The different distribution of these peptides in the human gestational tissues supports the hypothesis that they may serve different functions during pregnancy, although published data are still conflicting [129-131]. Similar profiles of Ucn2 mRNA and protein expression increase were assessed in mice during gestation, in which Ucn2 seemed to be implicated in the process of parturition [132]. In human trophoblast cell cultures, the endocrine actions of Ucn2, via CRHR2, include the regulation of aromatase activity and estrogen stimulation [133], and inhibition of placental 15-hydroxyprostaglandin dehydrogenase [134]. The immunoregulatory actions of Ucn2 also include amplification of placental lipopolysaccharide-induced [135] secretion of tumor necrosis factor (TNF)- and IL-10 [136]. These findings suggest that Ucn2 contributes to placental regulation in pregnancy and parturition events.

Concerning the diffuse endocrine cells in the female reproductive system, Watanabe et al. [31] detected Ucn2 in endometrial glands and epithelial cells of the rat uterus. mRNA levels of Ucn2 and CRHR2 in the uterus of mature rats were significantly higher in the diestrus phase than those in the proestrus phase, while plasma estrogen concentrations were significantly lower in the diestrus phase than in the proestrus phase. The uterine Ucn2/CRHR2 system might communicate with the estrogen system and may have regulatory roles in the estrous cycle. Ucn2 mRNA is strongly expressed in the uterus during the proliferative phase in healthy women, and this expression is abolished in patients with endometriosis [136]. In summary, the effects of Ucns on placental regulation, and in pregnancy and parturition events described in rodents and primates could be extended to farming animal species. Cows are frequently affected by retained fetal membranes, which represents a major problem in reproduction.

\section{Digestive system}

Extensive data on the distribution of Ucns and CRHRs in other organs suggest that these peptides have a more significant role in regulating the diffuse endocrine system. In this context, the expression of Ucns and their receptors as diffuse endocrine cells has mostly been found in the gastrointestinal tract of humans and rodents [45, 137-146]. Few papers described the expression of Ucns and their receptors in the diffuse endocrine gastrointestinal system of domestic animals. Particularly, Ucn1, CRHR1, and CRHR2 were detected in the distal colon fetuses from ovine species, where they were expressed in many sites and particularly in diffuse endocrine epithelial cells. Particularly, the co-localization of muscarinic receptor subtype M4 and weak CRHR2 signals on epithelial cell surface of colon fetuses suggests that these two receptors may modulate ion transport functions of the M3 subtype receptor. Strong CRH signals in the cytoplasm of luminal colonocytes and moderate Ucn1 signals in epithelial cells indicate that both neuropeptides may regulate epithelial M3 receptor-mediated ion transport under stress conditions via CRHR2. In adult animals, stress is known to induce epithelial dysfunction (breaking of the epithelial barrier) including mucin secretion and transmucosal fluxes of macromolecules and electrolytes $[147,148]$. Reports describing the localization of CRH and Ucn1 in enterochromaffin cells and enteric neurons of rodents and humans indicate that endocrine and neural tissues may function as local sources for both neuropeptides to mediate gastric inhibitory and colonic stimulatory motility effects via autocrine or paracrine mechanisms [137, 138, 144].

In the digestive apparatus of mammals, the pancreas is a glandular organ whose endocrine cells are organized in small clusters, the islets. UCN3 is strongly expressed in mammalian pancreatic beta cells and has been shown to stimulate insulin secretion. The expression pattern of UCN3 differs considerably between rodent and primate islets. While mouse UCN3 is restricted to beta-cells [149, 150], its expression in macaque (Macaca nemestrina) and human islets extends to the alpha-cells [149]. Consistent with this notion, Li et al. [150] have reported that exogenous UCN3, acting through CRHR2, stimulates insulin and glucagon secretion, particularly in the presence of nutrient excess. In rat and mouse insulin-secreting cell lines (INS-1 and MIN6), the expression levels of CRHR1 are notably higher than levels of CRHR2, a balance that can be overturned by exposure to glucocorticoids (GCs) [41]. The plasma glucose concentration and pancreatic insulin and glucagon secretion are relevant in various physiological states of domestic animals (i.e. lactation in dairy cattle). Several neuroendocrine substances are involved in these states. 


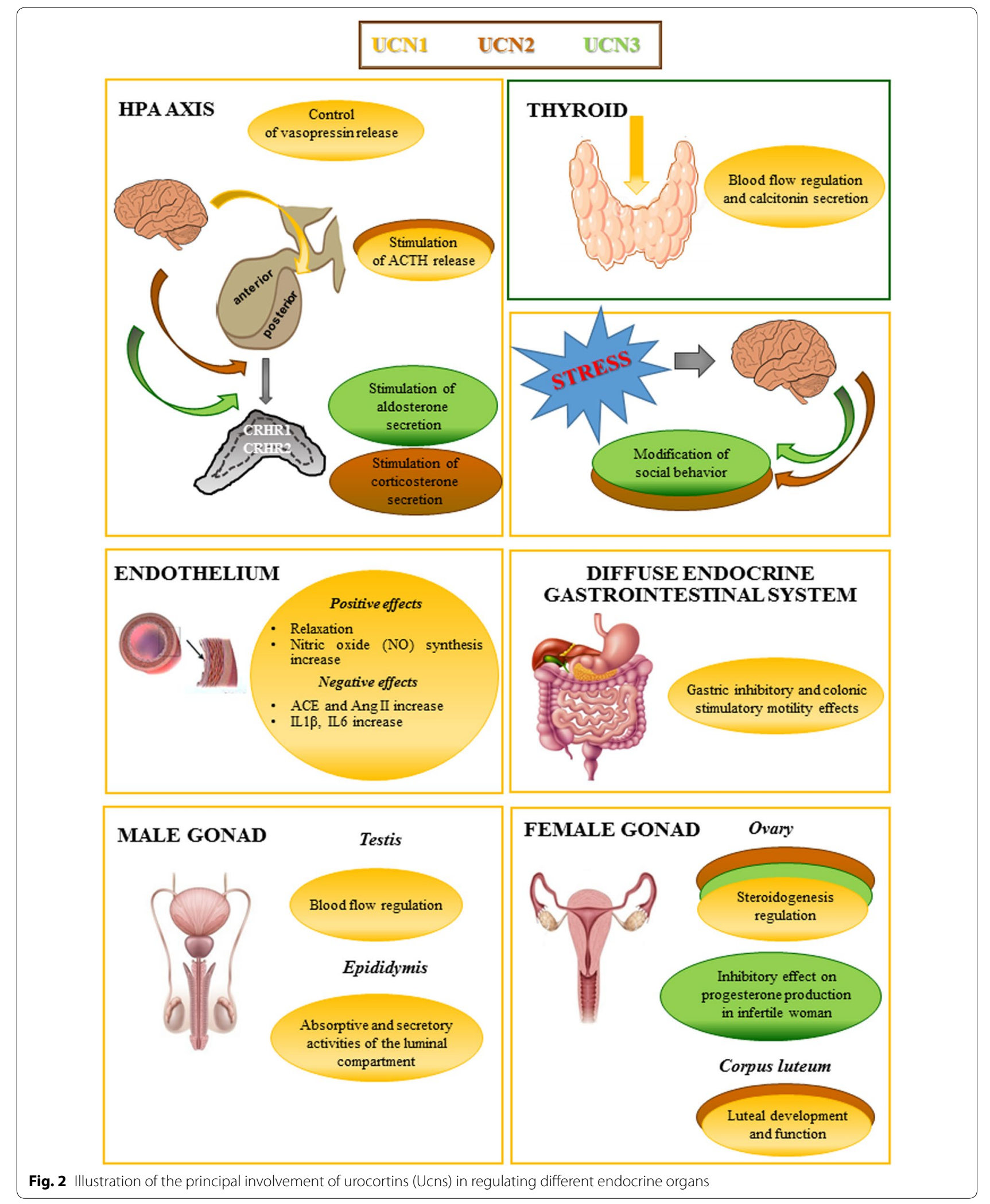




\section{Endothelium}

Situated at the interface between the blood and the inner wall of the vasculature, the endothelium is currently considered as not only a protective barrier, but also a central player that maintains cardiovascular homeostasis by secreting different substances. Ucn is one of these substances and has a dual effect on endothelium function [151, 152].

The endothelium, which also exhibits strong CRH-R2 expression, may contribute significantly to Ucn-induced vasodilation in some situations; deendothelialization was reported to reduce the vasodilatory action of Ucn 1 by as much as $50 \%$ in rat aorta [53]. Studies in rat and pig coronary arteries $[30,69,70]$ and human internal mammary arteries [73] indicate that Ucn1 endothelium-dependent dilation involves both nitric oxide (NO) (via second messenger cyclic guanosine mono- phosphate), prostaglandins, and barium-sensitive and calcium-activated potassium channels. Ucn1-related vasodilation of renal arteries is reported to be mediated by the production of cAMP, synthesis and release of sarcoplasmic $\mathrm{Ca}^{2+}$ as well as NO, and activation of potassium channels [74, 75].

\section{Conclusions}

The widely documented distribution of Ucns in different tissues of domestic animals provides evidence for the important biological role of these peptides in regulating bodily homeostasis. However, considering that more recent studies conducted on domestic animal species have used Ucn administration to evaluate its effects, the results obtained from this approach do not always give a complete and clear pattern of activity. Indeed, it is important to analyze the convolution of all the possible conditions causing endogenous ligand release, which involves an orchestrated complex of stress mediatorsneurotransmitters, neuropeptides and steroids - that are released throughout the entire brain.

Moreover, considering the important involvement of Ucns in different physiological and pathophysiological conditions related to the different endocrine glands (Fig. 2), they may be applied clinically to treat different diseases. This possibility is also derived from the wide spectrum of action shown by these neuropeptides at the central and peripheral level. Thus, future investigations addressing these aspects certainly could help fully characterize these peptides.

\section{Prior publication}

Data have not been published previously.

\section{Authors' contributions}

CS and NM fostered the idea of the review and coordinated the writing process. CS drafted the "Background" and the section titled "Urocortins and CRH receptors: general structure and biochemistry". AP drafted the section titled
"Hypothalamic-pituitary-adrenal and thyroid axis". GL drafted the sections titled "Gonads and reproductive system" and "Digestive system". All authors participated in the subsequent discussions and revisions of the entire text. All authors read and approved the final manuscript.

\section{Authors' information}

CS is a researcher in Veterinary Anatomy in the Department of Veterinary Medicine and Animal Productions, University of Naples Federico II, Italy. She has worked on the urocortinergic system in endocrine organs and other tracts of the mammalian body and has published extensively within this area. AP is a researcher in Veterinary Physiology in the Department of Advanced Biomedical Sciences, University of Naples Federico II and Institute of Biostructures and Bioimages, National Research Council. She is involved in the study of the urocortins in the mammalian endocrine system.

GL is a specialist in Veterinary Anatomy since 2012 and is involved in studying the urocortins and their receptors in the male genital tract of mammals in the Department of Veterinary Medicine and Animal Productions, University of Naples Federico II.

NM is a professor of Veterinary Anatomy in the Department of Veterinary Medicine and Animal Productions, University of Naples Federico II, having published numerous studies dealing with urocortins and their receptors in the several tracts of the mammalian body.

Funding

There has been no significant financial support for this review.

Ethics approval and consent to participate

This study did not require official or institutional ethical approval.

Consent for publication

Not applicable.

\section{Competing interests}

The authors declare that they have no competing interests.

\section{Author details}

${ }^{1}$ Department of Veterinary Medicine and Animal Productions, University of Naples Federico II, Via Veterinaria 1, 80137 Naples, Italy. ${ }^{2}$ Department of Advanced Biomedical Sciences, University of Naples Federico II, Via Pansini 5, 80131 Naples, Italy. ${ }^{3}$ Institute of Biostructures and Bioimages, National Research Council, Via De Amicis 95, 80131 Naples, Italy.

Received: 9 March 2019 Accepted: 21 September 2019

Published online: 04 October 2019

\section{References}

1. Montecucchi PC, Henschen A. Amino acid composition and sequence analysis of sauvagine, a new active peptide from the skin of Phyllomedusa sauvagii. Int J Pept Protein Res. 1981;18:113-20.

2. Lederis K, Letter A, McMaster D, Moore G, Schlesinger D. Complete amino acid sequence of urotensin I, a hypotensive and corticotropinreleasing neuropeptide from Catostomus. Science. 1982;218:162-5.

3. Reyes TM, Lewis K, Perrin MH, Kunitake KS, Vaughan J, Arias CA, et al. Urocortin Il: a member of the corticotropin-releasing factor (CRF) neuro- peptide family that is selectively bound by type 2 CRF receptors. J Am Coll Cardiol. 2001;98:2843-8.

4. Hauger RL, Grigoriadis DE, Dallman MF, Plotsky PM, Vale WW, Dautzenberg FM. International Union of Pharmacology. XXXVI. Current status of the nomenclature for receptors for corticotropin-releasing factor and their ligands. Pharmacol Rev. 2003;55:21-6.

5. Vale W, Spiess J, Rivier C, Rivier J. Characterizationofa41-residue ovine hypothalamic peptide that stimulates secretion of corticotropin and beta-endorphin. Science. 1981;213:1394-7.

6. Bale TL, Hoshijima M, Gu Y, Dalton N, Anderson KR, Lee KF, et al. The cardiovascular physiologic actions of urocortin II: acute effects in murine heart failure. Proc Natl Acad Sci USA. 2004:101:3697-702.

7. Dautzenberg FM, Hauger RL. The CRF peptide family and their receptors: yet more partners discovered. Trends Pharmacol Sci. 2002;23:71-7 
8. Vaughan J, Donaldson C, Bittencourt J, Perrin MH, Lewis K, Sutton S, et al. Urocortin, a mammalian neuropeptide related to fish urotensin I and to corticotropin-releasing factor. Nature. 1995;378:287-92.

9. Oki Y, Sasano H. Localization and physiological roles of urocortin. Peptides. 2004:25:1745-9.

10. De Luca A, Squillacioti C, Pero ME, Paino S, Langella E, Mirabella N. Urocortin-like immunoreactivity in the primary lymphoid organs of the duck (Anas platyrhynchos). Eur J Histochem. 2009;53:167-76.

11. Yang LZ, Tovote P, Rayner M, Kockskamper J, Pieske B, Spiess J. Corticotropin-releasing factor receptors and urocortins, links between the brain and the heart. Eur J Pharmacol. 2010;632:1-6.

12. Lee $S$, Braden B, Kang SS, Rivier C. Urocortins are present in the rat testis. Neuropeptides. 2011:45:131-7.

13. Squillacioti C, De Luca A, Liguori G, Paino S, Mirabella N. Expression of urocortin and corticotropin-releasing hormone receptors in the bovine adrenal gland. Gen Comp Endocrinol. 2011;172:416-22.

14. Squillacioti C, De Luca A, Ali S, Paino S, Liguori G, Mirabella N. Expression of urocortin and corticotropin-releasing hormone receptors in the horse thyroid gland. Cell Tissue Res. 2012;350:45-53.

15. Squillacioti C, De Luca A, Alì S, Ciarcia R, Germano G, Vittoria A, et al. Presence and distribution of urocortin and corticotrophin-releasing hormone receptors in the bovine thyroid gland. Anat Histol Embryol. 2014;43:429-34.

16. Lewis K, Li C, Perrin MH, Blount A, Kunitake K, Donaldson C, et al. Identification of urocortin III, an additional member of the corticotropinreleasing factor (CRF) family with high af nity for the CRF2 receptor. Proc Natl Acad Sci USA. 2011;98:7570-5.

17. Lovenberg TW, Liaw CW, Grigoriadis DE, Clevenger W, Chalmers DT, De Souza EB, et al. Cloning and characterization of a functionally distinct corticotropin-releasing factor receptor subtype from rat brain. Proc Natl Acad Sci USA. 1995:92:836-40.

18. Chen R, Lewis KA, Perrin MH, Vale WW. Expression cloning of a human corticotropin-releasing- factor receptor. Proc Natl Acad Sci USA. 1993;90:8967-71.

19. Potter E, Behan DP, Fischer WH, Linton EA, Lowry PJ, Sawchenko PE, et al. The central distribution of a corticotropin-releasing factor (CRF)binding protein predicts multiple sites and modes of inter- action with CRF. Proc Natl Acad Sci USA. 1992;89:4192-6.

20. Behan DP, De Souza EB, Lowry PJ, Potter E, Sawchenko P, Vale WW. Corticotropin releasing factor (CRF) binding protein: a novel regulator of CRF and related peptides. Front Neuroendocrinol. 1995;16:362-82.

21. KoziczT. CRF and CRF-related peptides in stress adaptation: from invertebrates to man. Gen Comp Endocrinol. 2007;153:198-209.

22. Gounko NV, Swinny JD, Kalicharan D, Jafari S, Corteen N, Seifi M, et al. Corticotropin-releasing factor and urocortin regulate spine and synapse formation: structural basis for stress-induced neuronal remodeling and pathology. Mol Psychiatry. 2013;18:86-92.

23. Dedic N, Chen A, Deussing JM. The CRF family of neuropeptides and their receptors - mediators of the central stress response. Curr Mol Pharmacol. 2018;11:4-31.

24. Deussing JM, Chen A. The corticotropin-releasing factor family: physiology of stress response. Physiol Rev. 2018;98:2225-86.

25. Ohata H, Suzuki K, Oki Y, Shibasaki T. Urocortin in the ventromedial hypothalamic nucleus acts as an inhibitor of feeding behavior in rats. Brain Res. 2000;861:1-7.

26. Imaki T, Katsumata H, Miyata M, Naruse M, Imaki J, Minami S. Expression of corticotropin releasing factor (CRF), urocortin and CRF type 1 receptors in hypothalamic-hypophyseal systems under osmotic stimulation. J Neuroendocrinol. 2001;13:328-38.

27. Kuperman Y, Chen A. Urocortins: emerging metabolic and energy homeostasis perspectives. Trends Endocrinol Metab. 2008;19:122-9.

28. Chen P, Vaughan J, Donaldson C, Vale W, Li C. Injection of urocortin 3 into the ventromedial hypothalamus modulates feeding, blood glucose levels, and hypothalamic POMC gene expression but not the HPA axis. Am J Physiol Endocrinol Metab. 2010;298:E337-45.

29. Yakabi K, Noguchi M, Ohno S, Ro S, Onouchi T, Ochiai M, et al. Urocortin 1 reduces food intake and ghrelin secretion via CRF(2) receptors. Am J Physiol Endocrinol Metab. 2011;301:E72-82.

30. Cottone P, Sabino V, Nagy TR, Coscina DV, Levin BE, Zorrilla EP. Centrally administered urocortin 2 decreases gorging on high-fat diet in both diet-induced obesity-prone and -resistant rats. Int J Obes. 2013;37:1515-23.

31. Watanabe K, Nemoto T, Akira S, Takeshita T, Shibasaki T. Estrogens downregulate urocortin 2 expression in rat uterus. J Endocrinol. 2013;219:269-78

32. Chang J, Adams MR, Clifton MS, Liao M, Brooks JH, Hasdemir B, et al. Urocortin 1 modulates immunosignaling in a rat model of colitis via corticotropin-releasing factor receptor. Am J Physiol Gastrointest Liver Physiol. 2011;300:G884-94.

33. Yamazaki T, Waki H, Kohsaka A, Nakamura T, Cui H, Yukawa K, et al. Microinjection of urocortin into the rat nucleus tractus solitarii decreases arterial blood pressure. Auton Neurosci. 2008;142:51-4.

34. Nakamura T, Sapru HN. Cardiovascular responses to microinjections of urocortins into the NTS: role of inotropic glutamate receptors. Am J Physiol Heart Circ Physiol. 2009;296:H2022-9.

35. Chitravanshi VC, Sapru HN. Microinjections of urocortin1 into the nucleus ambiguous of the rat elicit bradycardia. Am J Physiol Heart Circ Physiol. 2011;300:H223-9.

36. Gravanis A, Margioris AN. The corticotropin-releasing factor (CRF) family of neuropeptides in inflammation: potential therapeutic applications. Curr Med Chem. 2005;12:1503-12.

37. Florio P, Vale W, Petraglia F. Urocortins in human reproduction. Peptides. 2004;25:1751-7.

38. Wong ML, Al-Shekhlee A, Bongiorno PB, Esposito A, Khatri P, Sternberg $E M$, et al. Localization of urocortin messenger RNA in rat brain and pituitary. Mol Psychiatry. 1996;1:307-12.

39. Holloway AC, Howe DC, Chan G, Clifton VL, Smith R, Challis JR. Urocortin: a mechanism for the sustained activation of the HPA axis in the late-gestation ovine fetus? Am J Physiol Endocrinol Metab. 2002;283:E165-71.

40. Tsatsanis C, Dermitzaki E, Venihaki M, Chatzaki E, Minas V, Gravanis A, et al. The corticotropin-releasing factor (CRF) family of peptides as local modulators of adrenal function. Cell Mol Life Sci. 2007;64:1638-55.

41. Huising MO, Pilbrow AP, Matsumoto M, van der Meulen T, Park H, Vaughan JM, et al. Glucocorticoids differentially regulate the expression of CRFR1 and CRFR2a in MIN6 insulinoma cells and rodent islets. Endocrinology. 2011;52:138-50.

42. Grace CR, Perrin MH, Cantle JP, Vale WW, Rivier JE, Riek R. Common and divergent structural features of a series of corticotropin releasing factorrelated peptides. J Am Chem Soc. 2007;129:16102-14.

43. Donaldson CJ, Sutton SW, Perrin MH, Corrigan AZ, Lewis KA, Rivier J. Cloning and characterization of human urocortin. Endocrinology. 1996;137:2167-70.

44. Cepoi D, Sutton S, Arias C, Sawchenko P, Vale WW. Ovine genomic urocortin: cloning, pharmacological characterization, and distribution of central mRNA. Mol Brain Res. 1999:68:109-18.

45. Hsu SY, Hsueh AJ. Human stresscopin and stresscopin-related peptide are selective ligands for the type 2 corticotropin-releasing hormone receptor. Nat Med. 2001;7:605-11.

46. Chen A, Vaughan J, Vale WW. Glucocorticoids regulate the expression of the mouse urocortin II gene: a putative connection between the corticotropin-releasing factor receptor pathways. Mol Endocrinol. 2003;17:1622-39.

47. Grammatopoulos DK. Insights into mechanisms of corticotropinreleasing hormone receptor signal transduction. Br J Pharmacol. 2012;166:85-97.

48. Lewis K, Li C, Perrin MH, Blount A, Kunitake K, Donaldson C, et al. Identification of urocortin III, an additional member of the corticotropinreleasing factor (CRF) family with high affinity for the CRF2 receptor. Proc Natl Acad Sci USA. 2001;98:7570-5.

49. Chang CP, Pearse RV 2nd, O'Connell S, Rosenfeld MG. Identification of a seven transmembrane helix receptor for corticotropin-releasing factor and sauvagine in mammalian brain. Neuron. 1993;11:1187-95.

50. Vita N, Laurent P, Lefort S, Chalon P, Lelias JM, Kaghad M, et al. Primary structure and functional expression of mouse pituitary and human brain corticotrophin releasing factor receptors. FEBS Lett. 1993;335:1-5.

51. Dautzenberg FM, Dietrich K, Palchaudhuri MR, Spiess J. Identification of two corticotropin-releasing factor receptors from Xenopus laevis with high ligand selectivity: unusual pharmacology of the type 1 receptor. J Neurochem. 1997;69:1640-9. 
52. Myers DA, Trinh JV, Myers TR. Structure and function of the ovine type 1 corticotropin releasing factor receptor (CRF1) and a carboxyl-terminal variant. Mol Cell Endocrinol. 1998;144:21-35.

53. Tsai-Morris CH, Buczko E, Geng Y, Gamboa-Pinto A, Dufau ML. The genomic structure of the rat corticotropin releasing factor receptor. A member of the class II G protein-coupled receptors. J Biol Chem. 1996;271:14519-25.

54. Sakai K, Yamada M, Horiba N, Wakui M, Demura H, Suda T. The genomic organization of the human corticotropin-releasing factor type-1 receptor. Gene. 1998;219:125-30.

55. Ross PC, Kostas CM, Ramabhadran TV. A variant of the human corticotropin-releasing factor (CRF) receptor: cloning, expression and pharmacology. Biochem Biophys Res Commun. 1994;205:1836-42.

56. Pisarchik A, Slominski AT. Alternative splicing of $\mathrm{CRH}-\mathrm{R} 1$ receptors in human and mouse skin: identification of new variants and their differential expression. FASEB J. 2001;15:2754-6.

57. Catalano RD, Kyriakou T, Chen J, Easton A, Hillhouse EW. Regulation of corticotropin-releasing hormone type 2 receptors by multiple promoters and alternative splicing: identification of multiple splice variants. Mol Endocrinol. 2003;17:395-410.

58. Chen AM, Perrin MH, Digruccio MR, Vaughan JM, Brar BK, Arias CM, et al. A soluble mouse brain splice variant of type 2 corticotropin-releasing factor (CRF) receptor binds ligands and modulates their activity. Proc Natl Acad Sci. 2005;102:2620-5.

59. Evans RT, Seasholtz AF. Soluble corticotropin-releasing hormone receptor 2alpha splice variant is efficiently translated but not trafficked for secretion. Endocrinology. 2009;150:4191-202.

60. Henckens MJ, Deussing JM, Chen A. Region-specific roles of the corticotropin-releasing factor-urocortin system in stress. Nat Rev Neurosci. 2016;17:636-51

61. Grammatopoulos DK, Randeva HS, Levine MA, Kanellopoulou KA, Hillhouse EW. Rat cerebral cortex corticotropin-releasing hormone receptors: evidence for receptor coupling to multiple G-proteins. J Neurochem. 2001;76:509-19.

62. Ungless MA, Singh V, Crowder TL, Yaka R, Ron D, Bonci A. Corticotropinreleasing factor requires report $C R F$ binding protein to potentiate NMDA receptors via CRF receptor 2 in dopamine neurons. Neuron. 2003:39:401-7.

63. Slater PG, Cerda CA, Pereira LA, Andrés ME, Gysling K. CRF binding protein facilitates the presence of CRF type 2 receptor on the cell surface. Proc Natl Acad Sci USA. 2016;113:4075-80. https://doi.org/10.1073/ pnas.1523745113.

64. Uchoa ET, Aguilera G, Herman JP, Fiedler JL, DeakT, de Cordeiro Sousa MB. Novel aspects of hypothalamic-pituitary-adrenal axis regulation and glucocorticoid actions. J Neuroendocrinol. 2014;26:557-72.

65. Smith SM, Vale WW. The role of the hypothalamic-pituitary-adrenal axis in neuroendocrine response to stress. Dialogues Clin Neurosci. 2006;8:383-95.

66. Fekete C, Lechan RM. Central regulation of hypothalamic-pituitarythyroid axis under physiological and pathophysiological conditions. Endocr Rev. 2014;35:159-94.

67. May PJ, Reiner AJ, Ryabinin AE. Comparison of the distributions of urocortin-containing and cholinergic neurons in the perioculomotor midbrain of the cat and macaque. J Comp Neurol. 2008;507:1300-16.

68. Baigent SM, Lowry PJ. Urocortin is the principal ligand for the corticotrophin-releasing factor binding protein in the ovine brain with no evidence for a sauvagine-like peptide. J Mol Endocrinol. 2000;24:53-63.

69. Bittencourt JC, Vaughan J, Arias C, Rissman RA, Vale WW, Sawchenko PE. Urocortin expression in rat brain: evidence against a pervasive relationship of urocortin-containing projections with targets bearing type 2 CRF receptors. J Comp Neurol. 1999;415:285-312.

70. Rademaker MT, Charles CJ, Espiner EA, Fisher S, Frampton CM, Kirkpatrick $\mathrm{CM}$, et al. Beneficial hemodynamic, endocrine, and renal effects of urocortin in experimental heart failure: comparison with normal sheep. J Am Coll Cardiol. 2002:40:1495-505.

71. Kozicz T, Bittencourt JC, May PJ, Reiner A, Gamlin PD, Palkovits M, et al. The Edinger-Westphal nucleus: a historical, structural, and functional perspective on a dichotomous terminology. J Comp Neurol. 2011;519:1413-34.
72. Kozicz T, Yanaihara H, Arimura A. Distribution of urocortin-like immunoreactivity in the central nervous system of the rat. J Comp Neurol. 1998:391:1-10.

73. Asaba K, Makino S, Hashimoto K. Effect of urocortin on ACTH secretion from rat anterior pituitary in vitro and in vivo: comparison with corticotropin-releasing hormone. Brain Res. 1998;806:95-103.

74. Silvia WJ, McGinnis AS, Hatler TB. A comparison of adrenal gland function in lactating dairy cows with or without ovarian follicular cysts. Reprod Biol. 2005;5:19-29.

75. Riester A, Spyroglou A, Neufeld Cohen A, Chen A, Beuschlein F. Urocortin-dependent effects on adrenal morphology, growth, and expression of steroidogenic enzymes in vivo. J Mol Endocrinol. 2012;48:159-67.

76. Vetter DE, Li C, Zhao L, Contarino A, Liberman MC, Smith GW, et al. Urocortin-deficient mice show hearing impair- ment and increased anxiety-like behavior. Nat Genet. 2002;31:363-9.

77. Wang X, Su H, Copenhagen LD, Vaishnav S, Pieri F, Shope CD, et al. Urocortin-deficient mice display normal stress-induced anx- iety behavior and autonomic control but an impaired acoustic startle response. Mol Cell Biol. 2002;22:6605-10.

78. Deussing JM, Breu J, Kühne C, Kallnik M, Bunck M, Glasl L, et al. Urocortin 3 modulates social discrimination abilities via corticotropin-releasing hormone receptor type 2. J Neurosci. 2010;30:9103-16.

79. Neufeld-Cohen A, Evans AK, Getselter D, Spyroglou A, Hill A, Gil S, et al. Urocortin-1 and -2 double-deficient mice show robust anxiolytic phenotype and modified serotonergic activity in anxiety circuits. Mol Psychiatry. 2010;15:426-41.

80. Neufeld-Cohen A, Tsoory MM, Evans AK, Getselter D, Gil S, Lowry CA, et al. A triple urocortin knockout mouse model reveals an essential role for urocortins in stress recovery. Proc Natl Acad Sci USA. 2010;107:19020-5.

81. Parrott RF, Vellucci SV, Goode JA. Behavioral and hormonal effects of centrally injected "anxiogenic" neuropeptides in growing pigs. Pharmacol Biochem Behav. 2000;65:123-9.

82. Chalmers DT, Lovenberg TW, Grigoriadis DE, Behan DP, de Souza EB. Corticotrophin-releasing factor receptors: from molecular biology to drug design. Trends Pharmacol Sci. 1996;17:166-72.

83. Spiess J, Dautzinberg FM, Sydow S, Hauger RL, Rüh-mann A, Blank $T$, et al. Molecular properties of the CRF receptor. Trends Endocrinol Metab. 1998;9:140-5.

84. Holmberg BJ, Morrison CD, Keisler DH. Endocrine responses of ovariectomized ewes to i.c.v. infusion of urocortin. J Endocrinol. 2001:171:517-24.

85. Whitley NC, Barb CR, Kraeling RR, Barrett JB, Rampacek GB, Carroll JA, et al. Feed intake and serum GH, LH and cortisol in gilts after intracerebroventricular or intravenous injection of urocortin. Dom Anim Endocrinol. 2000;19:209-21.

86. Lubomirov LT, Gagov H, Petkova-Kirova P, Duridanova D, Kalentchuk VU, Schubert R. Urocortin relaxes rat tail arteries by a PKA-mediated reduction of the sensitivity of the contractile apparatus for calcium. Br J Pharmacol. 2001;134:1564-70.

87. Lubomirov LT, Reimann K, Metzler D, Hasse V, Stehle R, Ito M, et al. Urocortin-induced decrease in $\mathrm{Ca}^{2+}$ sensitivity of contraction in mouse tail arteries is attributable to CAMP-dependent dephosphorylation of MYPT1 and activation of myosin light chain phosphatase. Circ Res. 2006;98:1159-67.

88. Abdelrahman M, Syyong HT, Tjahjadi AA, Pang CC. Analysis of the mechanism of the vasodepressor effect of urocortin in anesthetized rats. Pharmacology. 2005;7:175-9.

89. Kateyama K, Sakihara S, Yamashita M, Kawashima S, Tanabe J, Suda T. A case of multiple endocrine neoplasia type ii accompanied by thyroid medullary carcinoma and pheochromocytomas expressing corticotropin-releasing factor and urocortins. Am J Med Sci. 2008;335:398-402.

90. Asakawa A, Fujimiya M, Niijima A, Fujino K, Kodama N, Sato Y, et al. Parathyroid hormone-related protein has an anorexigenic activity via activation of hypothalamic urocortins 2 and 3. Psychoneuroendocrinology. 2010;35:1178-86.

91. Dermitzaki E, Tsatsanis C, Minas V, Chatzaki E, Charalampopoulos I, Venihaki $\mathrm{M}$, et al. Corticotropin-releasing factor (CRF) and the urocortins differentially regulate catecholamine secretion in human and rat adrenals, in a CRF receptor type-specific manner. Endocrinology. 2007;148:1524-38. 
92. Nemoto T, Iwasaki-Sekino A, Yamauchi N, Shibasaki T. Regulation of the expression and secretion of urocortin 2 in rat pituitary. J Endocrinol. 2007;192:443-52.

93. Fekete ÉM, Zorrilla EP. Physiology, pharmacology, and therapeutic relevance of urocortins in mammals: ancient CRF paralogs. Front Neuroendocrinol. 2007;28:1-27.

94. Shemesh Y, Forkosh O, Mahn M, Anpilov S, Sztainberg Y, Manashirov S, et al. Ucn3 and CRF-R2 in the medial amygdala regulate complex social dynamics. Nat Neurosci. 2016;19:1489-96.

95. Wagner S. Urocortins and their unfolding role in mammalian social behavior. Cell Tissue Res. 2019;375:133-42.

96. Weisinger RS, Coghlan JP, Denton DA, Fan JS, Hatzikostas S, McKinley MJ, et al. ACTH-elicited sodium appetite in sheep. Am J Physiol. 1980;239:E45-50.

97. Blaine EH, Covelli MD, Denton DA, Nelson JF, Shulkes AA. The role of ACTH and adrenal glucocorticoids in the salt appetite of wild rabbits (Oryctolagus cuniculus (L.). Endocrinology. 1975;97:793-801.

98. Weisinger RS, Denton DA, Mckinley MJ, Nelson JF. ACTH induced sodium appetite in the rat. Pharmacol Biochem Behav. 1978:8:339-42.

99. Denton DA, Blair-West JR, McBurnie MI, Miller JA, Weisinger RS, Williams RM. Effect of adrenocorticotrophic hormone on sodium appetite in mice. Am J Physiol. 1999;277:R1033-40.

100. Blair-West JR, Denton DA, McBurnie M, Tarjan E, Weisinger RS. Influence of adrenal steroid hormones on sodium appetite of Balb/c mice. Appetite. 1995;24:11-24.

101. Weisinger RS, Blair-West JR, Burns P, Denton DA, McKinley MJ, Purcell $B$, et al. The inhibitory effect of hormones associated with stress on $\mathrm{Na}$ appetite of sheep. Proc Natl Acad Sci USA. 2000;97:2922-7.

102. Schulkin J, Marini J, Epstein AN. A role for the medial region of the amygdala in mineralocorticoid-induced salt hunger. Behav Neurosci. 1989;103:178-85.

103. Li Y, Song Z, Kerr KA, Moeser AJ. Chronic social stress in pigs impairs intestinal barrier and nutrient transporter function, and alters neuro-immune mediator and receptor expression. PLOS ONE. 2017;12:e0171617.

104. Squillacioti C, De Luca A, Liguori G, Ali S, Germano G, Vassalotti G, et al. Urocortinergic system in the testes of normal and cryptorchid dogs. Ann Anat. 2016;207:91-6.

105. Tezval H, Merseburger AS, Serth J, Herrmann TW, Becker JU, Jahn O, et al. Differential expression of urocortin in human testicular germ cells in course of spermatogenesis: role for urocortin in male fertility? Urology. 2009;73:901-5.

106. Tao J, Lin M, Sha J, Tan G, Soong TW, Li S. Separate locations of urocortin and its receptors in mouse testis: function in male reproduction and the relevant mechanisms. Cell Physiol Biochem. 2007;19:303-12.

107. McDowell EN, Kisielewski AE, Pike JW, Franco HL, Yao HH, Johnson KJ. A transcriptome-wide screen for mRNAs enriched in fetal Leydig cells: CRHR1 agonism stimulates rat and mouse fetal testis steroidogenesis. PLoS ONE. 2012;7:e47359.

108. Rivier CL. Urocortin 1 inhibits rat leydig cell function. Endocrinology. 2008; 149:6425-32.

109. Sumii K, Miyake H, Enatsu N, Chiba K, Fujisawa M. Characterization of urocortin as an anti-apoptotic protein in experimental ischemiareperfusion model of the rat testis. Biochem Biophys Res Commun. 2016:479:387-92.

110. De Luca A, Liguori G, Squillacioti C, Paino S, Germano G, Ali S, et al. Expression of urocortin and its receptors in the rat epididymis. Reprod Biol. 2014;14:140-7.

111. Liguori G, Squillacioti C, De Luca A, Ciarcia R, Vittoria A, Mirabella N. Presence and distribution of urocortin and its receptors in the epididymis of alpaca (Vicugna pacos). Anat Histol Embryol. 2015;44:66-71.

112. Arcuri F, Cintorino M, Florio P, Floccari F, Pergola L, Romagnoli R, et al. Expression of urocortin mRNA and peptide in the human prostate and in prostatic adenocarcinoma. Prostate. 2002;52:167-72.

113. Tezval H, Merseburger AS, Seidler M, Serth J, Kuczyk MA, Oelke M. Expression of corticotropin releasing factor receptor 2 (CRFR2) in the human prostate A new potential target for medical therapy of benign prostatic hyperplasia. Urologe. 2008;47:1079-80.

114. Tezval H, Jurk S, Atschekzei F, Serth J, Kuczyk MA, Merseburger AS. The involvement of altered corticotropin releasing factor receptor
2 expression in prostate cancer due to alteration of anti-angiogenic signaling pathways. Prostate. 2009;69:443-8.

115. Jin L, Zhang Q, Guo R, Wang L, Wang J, Wan R, et al. Different effects of corticotropin-releasing factor and urocortin 2 on apoptosis of prostate cancer cells in vitro. J Mol Endocrinol. 2011;47:219-27.

116. Sakumoto R, Ito S, Tokushi K. Possible actions of corticotropin-releasing hormone in regulating porcine corpus luteum function. J Vet Med Sci. 2010;72:1173-7.

117. Yu C, Li M, Wang Y, Liu Y, Yan C, Pan J, et al. MiR-375 Mediates CRH signaling pathway in inhibiting E2 synthesis in porcine ovary. Reproduction. 2016; pii: REP-16-0323.

118. Xu J, Hennebold JD, Stouffer RL. Dynamic expression and regulation of the corticotropin-releasing hormone/urocortin-receptor-binding protein system in the primate ovary during the menstrual cycle. J Clin Endocrinol Metab. 2006;91:1544-53.

119. Wypior G, Jeschke U, Kurpisz M, Szekeres-Bartho J. Expression of CRH, $\mathrm{CRH}$-related peptide and $\mathrm{CRH}$ receptor in the ovary and potential $\mathrm{CRH}$ signalling pathways. J Reprod Immunol. 2011;90:67-73.

120. Muramatsu Y, Sugino N, Suzuki T, Totsune K, Takahashi K, Tashiro A, et al. Urocortin and corticotropin-releasing factor receptor expression in normal cycling human ovaries. J Clin Endocrinol Metab. 2001;86:1362-9.

121. Asakura $\mathrm{H}$, Zwain $\mathrm{HH}$, Yen SS. Expression of genes encoding corticotropin-releasing factor (CRF), type 1 CRF receptor, and CRFbinding protein and localization of the gene products in the human ovary. J Clin Endocrinol Metab. 1997:82:2720-5.

122. Kalantaridou SN, Zoumakis E, Makrigiannakis A, Lavasidis LG, Vrekoussis T, Chrousos GP. Corticotropin-releasing hormone, stress and human reproduction: an update. J Reprod Immunol. 2010;85:33-9.

123. Yata A, Nakabayashi K, Wakahashi S, Maruo N, Ohara N, Maruo T. Suppression of progesterone production by stresscopin/urocortin 3 in cultured human granulosa-lutein cells. Hum Reprod. 2009:24:1748-53.

124. Spyroglou A, Riester A, Mueller-Peltzer K, Lu A, Rohde J, Hantel C, et al. Adrenal and ovarian phenotype of a tissue-specific urocortin 2-overexpressing mouse model. Endocrinology. 2015;156:2646-56.

125. Nappi RE, Rivest $\mathrm{S}$. Stress-induced genetic expression of a selective corticotropin-releasing factor-receptor subtype within the rat ovaries: an effect dependent on the ovulatory cycle. Biol Reprod. 1995;53:1417-28.

126. Lakshmanan J, Salido E, Ahanya S, Bronshtein E, Ross MG. Immunohistochemical localization of CRF-Urocortin family stress stimulators and inhibitors in sheep placnetome. J Soc Gynecol Investig. 2005;12:231A.

127. Petraglia F, Florio P, Gallo R, Simoncini T, Saviozzi M, Di Blasio AM, et al. Human placenta and fetal membranes express human urocortin mRNA and peptide. J Clin Endocrinol Metab. 1996;81:3807-10.

128. Imperatore A, Florio P, Torres PB, Torricelli M, Galleri L, Toti P, et al. Urocortin 2 and urocortin 3 are expressed by the human placenta, deciduas, and fetal membranes. Am J Obstet Gynecol. 2006;195:288-95.

129. Karteris E, Grammatopoulos D, Dai Y, Olah KB, Ghobara TB, Easton $A$, et al. The human placenta and fetal membranes express CRHR1alpha and the CRHR-C variant receptor. J Clin Endocrinol Metab. 1998;83:1376-9.

130. Florio P, Franchini A, Reis FM, Pezzani I, Ottaviani E, Petraglia F. Human placenta, chorion, amnion and decidua express different variants of corticotropin-releasing factor receptor messenger RNA. Placenta. 2000;21:32-7.

131. Aguilera G, Nikodemova M, Wynn PC, Catt KJ. Corticotropin releasing hormone receptors: two decades later. Peptides. 2004;25:319-29.

132. Voltolini C, Battersby S, Novembri R, Torricelli M, Severi FM, Petraglia $\mathrm{F}$, et al. Urocortin 2 role in placental and myometrial inflammatory mechanisms at parturition. Endocrinology. 2015;156:670-9.

133. Imperatore A, Li W, Petraglia F, Challis JR. Urocortin 2 stimulates estradiol secretion from cultured human placental cells: an effect mediated by the type 2 corticotrophin-releasing hormone (CRH) receptor. Reprod Sci. 2009;16:551e8.

134. Gao L, Lu C, Xu C, Tao Y, Cong B, Ni X. Differential regulation of prostaglandin production mediated by corticotropin-releasing hormone receptor type 1 and type 2 in cultured human placental trophoblasts. Endocrinology. 2008;149:2866-76.

135. Torricelli M, Novembri R, Bloise E, De Bonis M, Challis JR, Petraglia F. Changes in placental $\mathrm{CRH}$, urocortins, and $\mathrm{CRH}$-receptor mRNA expression associated with preterm delivery and chorioamnionitis. J Clin Endocrinol Metab. 2011;96:534-40. 
136. Novembri R, Torricelli M, Bloise E, Conti N, Galeazzi LR, Severi FM, et al. Effects of urocortin 2 and urocortin 3 on IL-10 and TNF-a expression and secretion from human trophoblast explants. Placenta. 2011;32:969-74

137. Kawahito Y, Sano H, Kawata M, Yuri K, Mukai S, Yamamura Y, et al. Local secretion of corticotropin-releasing hormone by enterochromaffin cells in human colon. Gastroenterology. 1994;106:859-65.

138. Harada S, Imaki T, Naruse M, Chikada N, Nakajima K, Demura H. Urocortin mRNA is expressed in the enteric nervous system of the rat. Neurosci Lett. 1999;267:125-8.

139. Kozicz T, Arimura A. Distribution of urocortin in the rat's gastrointestinal tract and its colocalization with tyrosine hydroxylase. Peptides. 2002;23:515-21.

140. Chatzaki E, Crowe PD, Wang L, Million M, Tache Y, Grigoriadis DE. CRF receptor type 1 and 2 expression and anatomical distribution in the rat colon. J Neurochem. 2004;90:309-16.

141. Chatzaki E, Murphy BJ, Wang L, Million M, Ohning GV, Crowe PD, et al. Differential profile of CRF receptor distribution in the rat stomach and duodenum assessed by newly developed CRF receptor antibodies. J Neurochem. 2004:88:1-11.

142. Chatzaki E, Lambropoulou M, Constantinidis TC, Papadopoulos N, Tache Y, Minopoulos G, et al. Corticotropin-releasing factor (CRF) receptor type 2 in the human stomach: protective biological role by inhibition of apoptosis. J Cell Physiol. 2006;209:905-11.

143. Porcher C, Juhem A, Peinnequin A, Sinniger V, Bonaz B. Expression and effects of metabotropic CRF1 and CRF2 receptors in rat small intestine. Am J Physiol Gastrointest Liver Physiol. 2005:288:G1091-103.

144. Porcher C, Peinnequin A, Pellissier S, Meregnani J, Sinniger V, Canini F, et al. Endogenous expression and in vitro study of CRFrelated peptides and CRF receptors in the rat gastric antrum. Peptides. 2005;27:1464-75.

145. Chang J, Hoy JJ, Idumalla PS, Clifton MS, Pecoraro NC, Bhargava A Urocortin 2 expression in the rat gastrointestinal tract under basal conditions and in chemical colitis. Peptides. 2007;28:1453-60.

146. Yuan PQ, Million M, Wu SV, Rivier J, Tache Y. Peripheral corticotropin releasing factor (CRF) and a novel CRF1 receptor agonist, stressin1-A activate CRF1 receptor expressing cholinergic and nitrergic myenteric neurons selectively in the colon of conscious rats. Neurogastroenterol Motil. 2007;19:923-36.

147. Lakshmanan J, Oyachi N, Ahanya SA, Liu G, Momeni M, Ross MG. Corticotropin-releasing factor inhibition of sheep fetal colonic contractility: mechanisms to prevent meconium passage in utero. Am J Obstet Gynecol. 2007;196(357):e1-7.

148. Lakshmanan J, Magee TR, Richard JD, Liu GL, Salido E, Sugano SK, et al. Localization and gestation-dependentpattern of corticotrophin-releasing factor receptor subtypes in ovine fetal distal colon. Neurogastroenterol Motil. 2008;20:1328-39.

149. van der Meulen T, Xie R, Kelly OG, Vale WW, Sander M, Huising MO. Urocortin 3 marks mature human primary and embryonic stem cellderived pancreatic alpha and beta cells. PLoS ONE. 2012;7:e52181.

150. Li C, Chen P, Vaughan J, Blount A, Chen A, Jamieson PM, et al. Urocortin III is expressed in pancreatic beta-cells and stimulates insulin and glucagon secretion. Endocrinology. 2003;144:3216-24.

151. Rademarker MT, Richards AM. Urocortins: actions in health and heart failure. Clin Chim Acta. 2017:474:76-87.

152. Yang C, Xu Y, Li S. Urocortin: a beneficial or detrimental agent to endothelium? Biochem Biophys Res Commun. 2008;371:345-9.

153. Grommen SVH, Scott MK, Darras VM, De Groef B. Spatial and temporal expression profiles of urocortin 3 mRNA in the brain of the chicken (Gallus gallus). J Comp Neurol. 2017;525:2583-91.

154. Khan MSI, Kaiya H, Tachibana T. Central injection of urocortin-3 but not corticotrophin-releasing hormone influences the ghrelin/GHS-R1a system of the proventriculus and brain in chicks. Domest Anim Endocrinol. 2014;47:27-34.

155. Buff PR, Whitley NC, McFadin-Buff EL, Keisler DH. Dose dependent decrease in feed intake following intravenous injection of urocortin into pony mares. J Anim Sci. 2001;78:149.

156. Smith F, Clark JE, Overman BL, Tozel CC, Huang JH, Rivier JE, et al. Early weaning stress impairs development of mucosal barrier function in the porcine intestine. Am J Physiol Gastrointest Liver Physiol. 2010;298:G352-63.

157. Sunagawa K, Mckinley MJ, Purcell BS, Thomson C, Burns PL. Effect of intracerebroventricular infusion of urocortin on feed and salt intake in parotid fistulated sheep. J Anim Sci. 2002;73:35-40.

\section{Publisher's Note}

Springer Nature remains neutral with regard to jurisdictional claims in published maps and institutional affiliations.
Ready to submit your research? Choose BMC and benefit from:

- fast, convenient online submission

- thorough peer review by experienced researchers in your field

- rapid publication on acceptance

- support for research data, including large and complex data types

- gold Open Access which fosters wider collaboration and increased citations

- maximum visibility for your research: over $100 \mathrm{M}$ website views per year

At BMC, research is always in progress.

Learn more biomedcentral.com/submissions 